\title{
STABILISED HETEROZYGOSIS OF SUPERGENES MEDIATING CERTAIN Y-LINKED COLOUR PATTERNS IN POPULATIONS OF LEBISTES RETICULATUS
}

\author{
CARYL P. HASKINS, PATRICIA YOUNG, RICHARD E. HEWITT \\ and EDNA F. HASKINS \\ Cornegie Institution of Woshington
}

Received 10.i.70

\section{INTRODUCTION}

INSTANCES of conspicuous morphological polymorphisms in natural populations that are mediated by sex-linked genes are, as Ford (1965) has recently emphasised, rather uncommon. They are, however, of unusual theoretical interest and in the case of man of special practical interest also, since the genes both for recessive red-green colour blindness and for a new blood group recently demonstrated by Mann and his colleagues (1962) are among those linked to the human $\mathrm{X}$ chromosome. Analogous Y-linked polymorphic supergenes have been observed even less often in natural animal populations. Ford (1965) has described two black forms of the moth Phigalia pilosaria, both industrial melanics, which appear to be under the control of genes lying in the non-pairing section of the $\mathrm{Y}$ chromosome. The findings of Clarke and Sheppard $(1959,1962)$ dealing with the inheritance of the black female form of Papilo glaucus (an apparent Batesian mimic of Battus philenor) suggest that the responsible gene-complex for this colour polymorphism lies in a (perhaps) non-pairing section of the $\mathrm{Y}$ chromosome in that butterfly.

It is perhaps surprising that so few instances of visible population polymorphisms controlled by strongly Y-linked gene complexes have in fact been observed in nature, since such linkage would seem to offer an efficient mode of ensuring continuing heterozygosity in such populations for linked loci which might mediate perhaps more biologically important characters as well. Two classic examples of this general sort in vertebrates, among Teleost fishes of the viviparous Cyprinodont family Poeciliidae, have, to be sure, long been studied. Colour polymorphism in the genus Xiphophorus, especially in $X$. maculatus, the Mexican platyfish, has been the subject of a long series of genetic investigations, notably by Gordon (1927, 1947, 1950, 1951) and his colleagues. These workers demonstrated the existence of a number of moderately tightly Y-linked supergenes for colour in X. maculatus. The highly colour-polymorphic Poeciliine species Lebistes reticulatus, the common guppy, native to north-eastern South America and adjacent West Indian islands (recently considered by some authorities to be inclusive in the genus Poecilia), presents an even more attractive subject for such studies. It was early exploited by Schmidt (1920), Winge (1922a, b, 1923, 1927, 1930, 1934), Winge and Ditlevsen (1938), and their colleagues, in whose hands it long ago became the classic "first" vertebrate animal in which the existence of " absolutely" Y-linked colour-polymorphic genes-or indeed of Y-linked morphological characters of any sort-was demonstrated. Yet elegant and decisive as was this demonstration, until recently it does not 
seem to have been utilised to any significant degree in studies of natural populations of Lebistes.

Lebistes, indeed, appears to offer unusually attractive opportunities to study the dynamics of Y-linked polymorphic supergenes in natural populations. Typically, wild guppy populations are plentiful and easily accessible and manipulable. Colour patterns well suited to genetic analysis are abundantly available, and with some practice can be readily distinguished from genetically unassessed colour backgrounds. The organism itself is hardy, breeds well in confinement, and can be collected from natural habitats for culture in the laboratory with a high proportion of survival. The cycle from birth to maturity is normally of the order of three months.

For a number of years we have been studying such natural populations of Lebistes in selected rivers of the Northern Range of Trinidad. These are permanent waters. They have the further virtue that they offer considerable variety in terms of the " cosmopolitan" character of their Lebistes populations. Thus some of the streams (those flowing down the northern face of the Range and emptying into the sea) provide essentially isolated habitats for Lebistes populations. In other streams, however, which course down the southern face of the Range to join a major common river, the westwardflowing Caroni, Lebistes populations are isolated only by distance, and in lowland reaches merge with a larger and genetically richer general population inhabiting the stretches of the main river between them. All these tributary streams offer a variety of microhabitats, differing substantially in illumination, volume of water, rate of water flow, and mean annual temperature. Reports of some preliminry studies, designed primarily to set the stage for more extensive and detailed investigations of Lebistes populations in these microhabitats, have appeared (Haskins and Haskins, 1950, 1951, 1954; Haskins, Haskins, McLaughlin, and Hewitt, 1961), and further work is in progress. As a corollary to it, more thorough understanding of genetic mechanisms which seem to maintain permanent heterozygosity at loci for a number of " absolutely" Y-linked colour patterns in such populations seemed important. How tightly some supergenes of this class can be linked to the $\mathrm{Y}$ chromosome has been well illustrated by the fact that cross-over to the $\mathrm{X}$ chromosome of the supergene for the colour pattern Maculatus, first described by Winge in $1922(1922 a, b)$, was never observed in the course of a quarter-century of continuous study in his laboratory. Winge kindly supplied us with this stock in 1934, and it has been under continuous culture in our laboratory ever since. A close watch for such spontaneous cross-over has thus been maintained over the following 35 years. During a total span of laboratory culture of 60 years, involving almost 250 generations and many thousands of individuals, only a single instance of cross-over has been detected at this locus, and it involved only a part of the pattern. Similar situations obtain for other " absolutely" Y-linked colour patterns first investigated by Winge, such as Armatus and Pauper which have been kept under observation, first in his laboratory, and then in ours, for almost as many generations.

By contrast, a considerable series of X-linked colour genes is known in Lebistes. A number, such as the Coccinneus-Vitellinus complex originally isolated and described by Winge (1927), have been adequately studied and do not appear remarkable, typically exhibiting measurable, and even considerable, cross-over values between $\mathrm{X}$ and $\mathrm{Y}$ chromosomes.

With one exception to be described, all sex-linked colour patterns studied 
in Lebistes, whatever their chromosome linkage, behave as dominants, and when two or more are present, their additive effects are visible in the male. With this exception, all are completely sex-limited in expression, being phenotypically absent in the adult female and in the young of both sexes. When females are appropriately treated with methyl testosterone, however, $\mathrm{X}$-linked patterns become clearly visible, offering a rapid and relatively efficient method of analysing the colour-genotype of such adult females.

An early and intriguing - though not unexpected-finding in our studies of the distribution of pattern genes in wild populations of Lebistes (Haskins, Haskins, McLaughlin, and Hewitt, 1961) was that, in relatively large populations inhabiting extensive bodies of water, or taken from tributary stream locations immediately confluent with these-populations that probably experienced a considerable "flow-through" of pattern-genes over time (and where, also, natural fish predators of Lebistes were abundant)-almost all the colour patterns in the population appeared to be mediated by supergenes tightly linked to the $\mathrm{Y}$ chromosome. Females from such populations, when treated with methyl testosterone in the manner described, gave evidence of few if any colour factors in the genotype. Correspondingly, males from such populations showed strict Y-linkage of colour patterns selected for analysis. This situation has since been further confirmed for a number of similar environments further afield, including other lowland streams in Trinidad, and coastal waters of Venezuela, British Guiana and Surinam. In sharp contrast, females taken in small, isolated populations inhabiting the head waters of highland streams or similarly isolated minor bodies of water (usually, also, free of serious fish predators) typically show a considerable colour-content in the genotype, and males on breeding exhibit a good proportion of X-linked colour patterns. This situation, also, has been well confirmed in populations from various locations in the Northern Range of Trinidad and in Tobago.

Such findings, of course, are consistent with a general characteristic of populations of polymorphic organisms. Typically, large populations, situated at the "depots" of considerable gene-flows, exhibit a high degree of genetic diversity among their members, while the reverse is true of small and genetically isolated populations. Lebistes populations can offer unusually dramatic illustrations of this situation, for on occasion the switch from one pattern of linkage-distribution to the other can be detected in populations apparently continuous along as little as eight miles of a stream course. Thus we are returned to the original question. What is the nature of the genetic mechanisms which may stabilise the heterozygosity of certain Y-linked supergenes in the larger, more cosmopolitan populations?

It has been postulated (Darlington and Mather, 1949) that the stable heterozygosity of Y-linked pattern genes in Lebistes can be entirely accounted for by the fact that all such supergenes are mechanically tightly linked to a non-pairing section of the $\mathrm{Y}$ chromosome, behaving there as alleles or "super-alleles" in Ford's sense. A first hint that the mechanism may actually be more complex than this, possibly involving recessive lethals linked to colour-pattern supergenes and thus "protected" in evolution so long as the principal loci remain heterozygous, was provided by Winge (1934) and Winge and Ditlevsen (1938). These investigators succeeded in detecting a very few naturally occurring functional $\mathrm{XY}$ females in their stocks of Maculatus by a very slight breakdown of the normal sex-limitation of this 
Y-linked pattern in these individuals. In crossing them with normal XY males carrying the similarly "absolutely" Y-linked pattern Pauper, the investigators recovered among the progeny a proportion of $\mathrm{YY}$ males having the additive pattern Maculatus-Pauper. Such males proved fully viable and fertile. Statistical consideration of the necessarily limited data from these broods suggested that the proportion of purely Maculatus males among the $\mathrm{F}_{1}$ progeny was significantly below expectation and led Winge to surmise that YY males homozygous for the Maculatus pattern were inviable, pointing to the existence of a recessive lethal linked to that supergene.

Work of this kind could be carried no further so long as no sex-linked but not sex-limited colour genes were known for Lebistes. For though phenotypic reversal of sex in either direction can be readily accomplished in Lebistes with appropriate mammalian hormones, fry must be treated within a week or so after birth, before gonadal differentiation has progressed far, if the reversal is to be physiologically significant. Since sex-limited colour patterns are typically cryptic in both $\mathrm{XX}$ and $\mathrm{XY}$ young before sexual maturity at approximately three months of age, the lack of any practical means of distinguishing the sex genotype of fry at birth has hitherto posed a fatal block to preparing functional females of XY genotype in the quantities required for well-controlled experimental work of this kind.

That block has now been fortunately removed by the discovery of a new colour mutation in a domestic stock of Lebistes in Germany about 1956, inherited, as Dzwillo (1959) has shown, as an X-linked dominant. This mutant gene mediates a heavy melanin development over the entire body area posterior to the dorsal fin, and in the caudal peduncle. Males are so darkened by this melanin overlay that other colour patterns may be nearly or wholly obscured. Unlike any of the colour factors recorded from wild populations, this gene is not sex-limited in expression, being clearly exhibited in females even in heterozygous condition. Furthermore, it is markedly evident in fry shortly after birth. By incorporating it in suitable crosses, the genotypes of larvae can be reliably identified at an age when the gonads are still undetermined and functional sex reversal with mammalian hormones is fully practicable. It would be difficult to over-emphasise the practical value of this mutant. It has made possible the work described herewith.

Several questions were of interest. First, it seemed important to repeat the work of Winge and his associates, employing considerably larger numbers of females of genetic constitution $\mathrm{X}_{0} \mathrm{Y}_{\text {Maculatus }}$ to further investigate the comparative viability and fertility of YY males heterozygous and homozygous for that pattern supergene. Second, it seemed of interest to determine in like fashion the situation for some additional pattern supergenes known to behave as though similarly tightly Y-linked. Finally, if it proved that YY males homozygous for more than one of these patterns were infertile or nonviable, it would be of further interest to determine whether recessive subvital or lethal genes linked to those colour-mediating gene complexes behaved as alleles among themselves.

\section{Materials}

The three "absolutely" Y-linked patterns earlier discussed were chosen for investigation. The Maculatus supergene has been maintained in laboratory culture since July 1916 (Winge, 1922b). The original stock carrying 
this pattern, known as the "spot race", appears to have been obtained from Johannes Schmidt, with whom Winge was associated, possibly as early as 1915. The pattern was not again recovered from the wild for many years. We failed to detect it in Trinidad populations over nearly forty years of search. Recently, however, we have recovered it from wild stocks collected near Paramaribo, Surinam, in coastal populations by Sergent J. Pjipers in 1968. The wild founding stock carrying the supergene for Pauper was collected in the "Danish West Indies" at an unrecorded date (Winge, 1927) but probably close to 1922. Armatus founding stock was obtained commercially in Copenhagen by Winge in 1922 (Winge, 1927). No crossover of either pattern from $\mathrm{Y}$ to $\mathrm{X}$ has been observed, either in Winge's laboratory or in our own, as already mentioned.

\section{Methods AND GRosses}

The concentrations and method of application of the mammalian androgens used to induce sex differentiation opposite to genotype followed the general patterns described by Yamamoto (1953, 1955, 1958) for Oryzias latipes and earlier by Grobstein (1948) for Xiphophorus maculatus.

Methyl testosterone was used in concentration of I mg. of U.S.P. methyl testosterone (crystalline) per gram of a standard moist fish-food. Treated stock were fed once per day, together with regular non-hormone feeding once per day.

Estrone was used in concentration of $1 \mathrm{~g}$. of Estradiol (U.S.P. crystalline) per $50 \mathrm{~g}$. of the same standard moist mixture. Treated stock were fed once per day together with non-hormone feeding once per day.

The crosses employed were of the following simple design:

$A$ (a) Female $\mathrm{X}_{\mathrm{BI}} \mathrm{X}_{\mathrm{BI}} \times$ male $\mathrm{X}_{0} \mathrm{Y}_{\mathrm{M}}$, yielding mlaes $\mathrm{X}_{\mathrm{BI}} \mathrm{Y}_{\mathrm{M}}$,

(b) Female $\mathrm{X}_{0} \mathrm{X}_{0} \times$ male $\mathrm{X}_{\mathrm{Bl}} \mathrm{Y}_{\mathrm{M}}$, yielding young $\mathrm{X}_{\mathrm{Bl}} \mathrm{X}_{0}+\mathrm{X}_{0} \mathrm{Y}_{\mathrm{M}}$,

where $\mathrm{M}=$ dominant $\mathrm{Y}$-linked character under investigation-i.e. Maculatus (Ma); Armatus (Ar); or Pauper (Pa).

The non-Black (XY) fry from this cross were treated with estrone to produce females of constitution $\mathrm{X}_{0} \mathrm{Y}_{\mathrm{M}}$.

By this means, functional $\mathrm{XY}$ females carrying any desired $\mathrm{Y}$-linked colour-pattern supergenes, analogous to the naturally occurring $\mathrm{X}_{0} \mathrm{Y}_{\mathrm{Ma}}$ females detected by Winge, can readily be produced at will and in any numbers desired.

(c) Female $\mathrm{X}_{0} \mathrm{Y}_{\mathrm{M}} \times$ male $\mathrm{X}_{0} \mathrm{Y}_{\mathrm{N}}$ yielding females $\mathrm{X}_{0} \mathrm{X}_{0}+$ males $\mathrm{X}_{0} \mathrm{Y}_{\mathrm{M}}+$ males $\mathrm{X}_{0} \mathrm{Y}_{\mathrm{N}}+$ males $\mathrm{Y}_{\mathrm{M}} \mathrm{Y}_{\mathrm{N}}$,

where $N=$ a second dominant $Y$-linked character under investigation. The YY males are readily detected by inspection of their "double" colour patterns.

A second equally simple design of crosses can then be performed to test the fertility or viability of $\mathrm{YY}$ males carrying any $\mathrm{Y}$-linked pattern in homozygous condition:

$B$ (a) Female $\mathrm{X}_{\mathrm{Bl}} \mathrm{X}_{\mathrm{Bl}} \times$ male $\mathrm{Y}_{\mathrm{M}} \mathrm{Y}_{\mathrm{N}}$, yielding $\mathrm{X}_{\mathrm{Bl}} \mathrm{Y}_{\mathrm{M}}+\mathrm{X}_{\mathrm{Bl}} \mathrm{Y}_{\mathrm{N}}$ young. This all-Black brood, when treated as fry with estrone, should theoretically contain equal numbers of functional $\mathrm{X}_{\mathrm{BI}} \mathrm{Y}$ females including each of the 
two Y-linked pattern genes under study. The two classes of females, of course, cannot be separated by inspection.

(b) Female $\mathrm{X}_{\mathrm{Bl}} \mathrm{Y}_{\mathrm{M}}$ or female $\mathrm{X}_{\mathrm{Bl}} \mathrm{Y}_{\mathrm{N}} \times$ male $\mathrm{Y}_{\mathrm{M}} \mathrm{Y}_{\mathrm{N}}$,

which, if the XY pattern of sex determination normal to Lebistes is maintained, should yield all-male broods of constitution

$\left(\right.$ male $\mathrm{X}_{\mathrm{Bl}} \mathrm{Y}_{\mathrm{M}}$ or male $\left.\mathrm{X}_{\mathrm{Bl}} \mathrm{Y}_{\mathrm{N}}\right)+\left(\right.$ male $\mathrm{Y}_{\mathrm{M}} \mathrm{Y}_{\mathrm{M}}$ or male $\left.\mathrm{Y}_{\mathrm{N}} \mathrm{Y}_{\mathrm{N}}\right)+$ male $\mathrm{Y}_{\mathrm{M}} \mathrm{Y}_{\mathrm{N}}$.

All non-Black (and thus $\mathrm{YY}$ ) males should be assessible by inspection as either homozygous $\mathrm{M}$ or $\mathrm{N}$, or heterozygous $\mathrm{M}-\mathrm{N}$.

\section{Maculatus-Armatus}

\section{Results}

$A$. Employing the procedures in $A$ above, females of constitution $\mathrm{X}_{0} \mathrm{Y}_{\mathrm{Ar}}$ were prepared in some numbers and used to investigate the fertility and viability of heterozygous $\mathrm{Y}_{\mathrm{Ar}} \mathrm{Y}_{\mathrm{Ma}}$ males. Crosses to produce females $\mathrm{X}_{\mathbf{0}} \mathrm{Y}_{\mathrm{Ma}}$ and $\mathrm{X}_{0} \mathrm{Y}_{\mathrm{Ar}}$ and males $\mathrm{Y}_{\mathrm{Ma}} \mathrm{Y}_{\mathrm{Ar}}$ are shown in plate $\mathrm{I}$, a-c. The results were:

1 (a) Female $\mathrm{X}_{0} \mathrm{Y}_{\mathrm{Ar}} \times$ male $\mathrm{X}_{0} \mathrm{Y}_{\text {Ma }}$ yielded 157 males $\mathrm{X}_{0} \mathrm{Y}_{\mathrm{Ar}}: 133$ males $\mathrm{X}_{0} \mathrm{Y}_{\mathrm{Ma}}$ : 124 males $\mathrm{Y}_{\mathrm{Ar}} \mathrm{Y}_{\mathrm{Ma}}: 183$ females.

This is a ratio of 414 males : 183 females, or 2.3 males : 1 female, a marked deficiency of males from the theoretical ratio of $3: 1$.

Many of the $\mathrm{Y}_{\mathrm{Ar}} \mathrm{Y}_{\mathrm{Ma}}$ males were tested for fertility (table 1, below). All proved fully fertile as well as viable. Longevity tests showed life-spans at least equal to those of normal XY males. Activity and aggressiveness were, if anything, higher in the heterozygous YY males.

(b) A sample of 92 mature females from the group of 183 was treated with methyl testosterone. Of these, 85 , or 92.4 per cent., proved to lack expressible colour genes entirely and were presumably of the expected composition $\mathrm{X}_{0} \mathrm{X}_{0}$. Five, however, carried the pattern Armatus, and were presumably of the composition $\mathrm{X}_{0} \mathrm{Y}_{\mathrm{Ar}}$, while 1 carried the pattern Maculatus, and presumably was $\mathrm{X}_{0} \mathrm{Y}_{\mathrm{Ma}}$. If the percentage of $\mathrm{XY}$ or $\mathrm{YY}$ females in this sample be assumed to hold for the entire sample of females, the number would have been 13.9 (14), and the ratio of XY or YY progeny to XX then becomes $428: 169$, or $2 \cdot 53: 1$, considerably closer to theory.

These latter females, incidentally, confirm and emphasise Winge's original hypothesis that autosomally distributed sex-determining genes function importantly in Lebistes in conjunction with those linked to the sex chromosomes.

(c) Female $\mathrm{X}_{0} \mathrm{Y}_{\mathrm{Ma}} \times$ male $\mathrm{X}_{0} \mathrm{Y}_{\mathrm{Ar}}$ (the reciprocal of 1 (a) above) yielded 254 males $\mathrm{X}_{0} \mathrm{Y}_{\mathrm{Ar}}$ : 188 males $\mathrm{X}_{0} \mathrm{Y}_{\mathrm{Ma}}: 242$ males $\mathrm{Y}_{\mathrm{Ar}} \mathrm{Y}_{\mathrm{Ma}}: 343$ females.

This is a ratio of 684 males : 343 females $=2.0$ males : 1 female, a slightly greater deficiency of males below the theoretical $3: 1$ ratio than in $1(a)$.

(d) A sample of 260 adult phenotypic $F_{1}$ females from this cross was treated with methyl testosterone, as above. Of these, 230 , or 88.5 per cent., proved to be $\mathrm{X}_{0} \mathrm{X}_{0} ; 25$ were $\mathrm{X}_{0} \mathrm{Y}_{\mathrm{Ma}} ; 3$ were $\mathrm{X}_{0} \mathrm{Y}_{\mathrm{Ar}}$; and 2, again, were females of composition $\mathrm{Y}_{\mathrm{Ma}} \mathrm{Y}_{\mathrm{Ar}}$, emphasising once more the lability of the balances involved in sex determination in Lebistes. If the proportion of females of $\mathrm{XY}$ and $\mathrm{YY}$ composition in this tested sample is again assumed, as in $1(b)$, to hold for the entire group of females, their number in that group would have been $40(39.5)$. Correcting, as in $1(a)$ the ratio of 
$(\mathrm{XY}+\mathrm{YY}): \mathrm{XX}$ individuals becomes $724: 303=2 \cdot 4: 1$, with the former class again deficient.

\section{Viability of heterozygous $Y Y$, compared with $X Y$ males}

In cross $1(a)$ above, the ratio of heterozygous YY males to XY males of both types is $124: 290$, or $1: 2 \cdot 3$, a slight deficiency of YY males over the theoretically expected $1: 2 \cdot 0$. In the reciprocal cross, $1(c)$ the corresponding ratio is $242: 442=1: 1 \cdot 8$, a slight excess. For both crosses taken together, the corresponding ratios are $366: 732$, or precisely the expected ratio of $1: 2 \cdot 0$. No difference in viability, therefore, could be demonstrated between males of heterozygous YY composition and normal XY males.

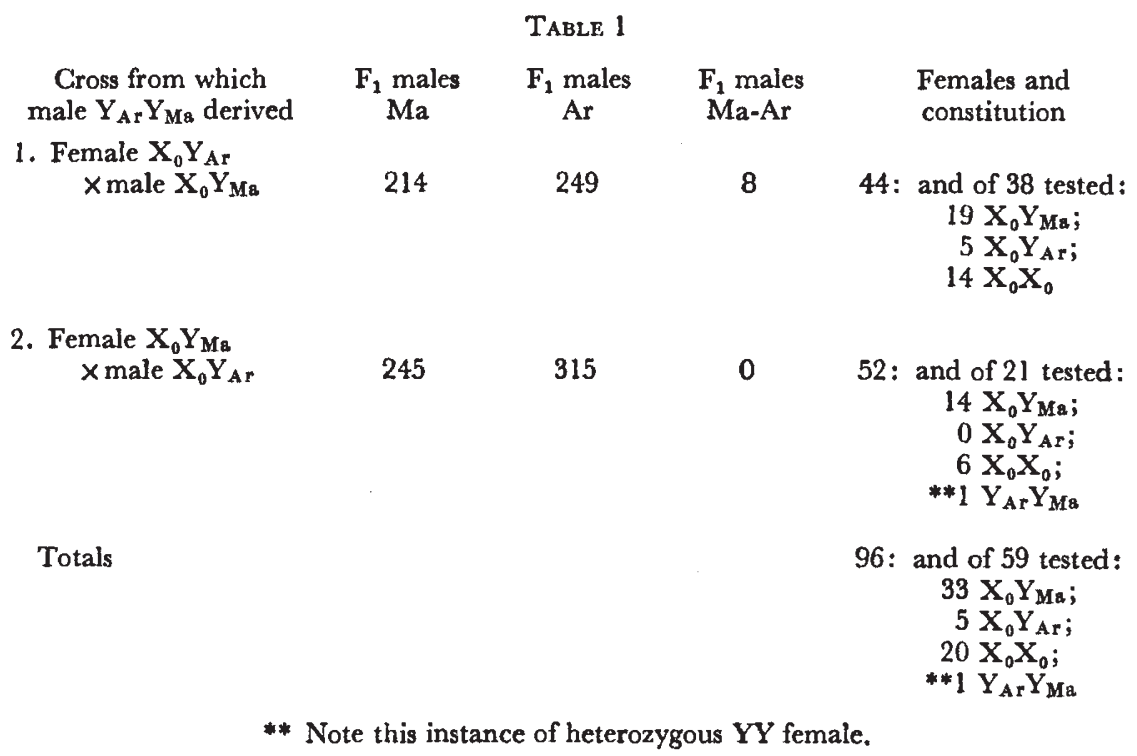

Fertility of $Y Y$ males, Back-cross to $X_{0} X_{0}$ females

To test the fertility of these $\mathrm{Y}_{\mathrm{Ar}} \mathrm{Y}_{\mathrm{Ma}}$ males, as well as to check on the possibility of cross-over between the two $Y$ chromosomes and to add information on the relative viability of $\mathrm{Y}$ chromosomes labelled respectively with $M a$ and $A r$ derived from the same individual, such heterozygous YY males were back-crossed to females of constitution $\mathrm{X}_{0} \mathrm{X}_{0}$ with the results given in table 1. The types are shown in plate II, $a$ and $b$.

Glearly, the heterozygous YY males were fully fertile as well as viable. Second, if the proportion of females of constitution $\mathrm{X}_{0} \mathrm{Y}_{\mathrm{Ma}}$ was the same for all 96 females produced as in the 59 tested, there could have been expected $53 \mathrm{X}_{0} \mathrm{Y}_{\mathrm{Ma}}$ females and $8 \mathrm{X}_{0} \mathrm{Y}_{\mathrm{Ar}}$. Adding these $\mathrm{Y}$ chromosomes to those of the males above, the total becomes, respectively, $512 \mathrm{Ma}$-labelled Y chromosomes to $572 A r$-labelled chromosomes, suggesting a somewhat greater viability for $A r$-labelled chromosomes under the given conditions.

The special case of $A r-M a$ individuals ( 8 males from cross 1 above and 1 female from cross 2) raised a question of interest. Did these represent crossovers between the $\mathrm{Y}$ chromosomes, or were both $\mathrm{Y}$ chromosomes transmitted together? 
Two of the $8 \mathrm{Ar}-\mathrm{Ma}$ males shown above were re-crossed to females from Pauper stock of $\mathrm{X}_{0} \mathrm{X}_{0}$ constitution with the results: $131 \mathrm{~F}_{1}$ males $\mathrm{X}_{0} \mathrm{Y}_{\mathrm{Ma}}$; 123 males $\mathrm{X}_{0} \mathrm{Y}_{\mathrm{Ar}} ; 0$ males $\mathrm{Y}_{\mathrm{Ma}} \mathrm{Y}_{\mathrm{Ar}} ; 6$ females $\left(5\right.$ masculinised, all $\mathrm{X}_{0} \mathrm{Y}_{\mathrm{Ma}}$ ). Thus there was no further occurrence of $\mathrm{Y}_{\mathrm{Ar}} \mathrm{Y}_{\mathrm{Ma}}$ in individuals of either sex in the following generation. It seems unlikely, therefore, that cross-over between $A r$-marked and $M a$-marked Y chromosomes had occurred. It is perhaps worth noting that in this back-cross, unlike the original one, the $M a$-marked Y chromosomes predominated.

\section{Viability of homozygous $r r_{\text {males: }} \Upsilon_{A r} \Upsilon_{A r} ; r_{M a} \Upsilon_{M a}$}

Crosses were made to test the viability of homozygous YY males$\mathrm{Y}_{\mathrm{Ma}} \mathrm{Y}_{\mathrm{Ma}}$ and $\mathrm{Y}_{\mathrm{Ar}} \mathrm{Y}_{\mathrm{Ar}}$ (plate III, a and b).

2 (a) The cross: female $\mathrm{X}_{\mathrm{Bl}} \mathrm{Y}_{\mathrm{Ar}}$ or female $\mathrm{X}_{\mathrm{Bl}} \mathrm{Y}_{\mathrm{Ma}}$ (derived from cross $B(a)$ above, with estrone treatment) $\times$ male $\mathrm{Y}_{\mathrm{Ar}} \mathrm{Y}_{\mathrm{Ma}}$ yielded 750 males $\left(\mathrm{X}_{\mathrm{Bl}} \mathrm{Y}_{\mathrm{Ar}}+\mathrm{X}_{\mathrm{Bl}} \mathrm{Y}_{\mathrm{Ma}}\right.$, phenotypically indistinguishable) : 389 males $\mathrm{Y}_{\mathrm{Ar}} \mathrm{Y}_{\mathrm{Ma}}: 23$ males $\operatorname{Ar}\left(\mathrm{Y}_{\mathrm{Ar}} \mathrm{Y}_{\mathrm{Ar}}\right.$ ?) : 27 males $\mathrm{Ma}\left(\mathrm{Y}_{\mathrm{Ma}} \mathrm{Y}_{\mathrm{Ma}}\right.$ ?).

There were also 88 Black females (either $\mathrm{X}_{\mathrm{Bl}} \mathrm{X}_{0}$ or $\mathrm{X}_{\mathrm{Bl}} \mathrm{Y}$ ), and 11 uncoloured females. Of a sample of 4 of the last analysed for colour content with methyl testosterone, 3 were $\mathrm{X}_{0} \mathrm{Y}_{\mathrm{Ma}}$, and 1 was $\mathrm{X}_{0} \mathrm{X}_{0}$.

In this cross, all individuals bearing an $\mathrm{X}$ chromosome marked with Black (and therefore Black) should be equal to twice the sum of XY or YY non-Black individuals. The actual totals were: 838 Black $(750$ males +88 females) : 439 non-Black (389 males $\mathrm{Y}_{\mathrm{Ar}} \mathrm{Y}_{\mathrm{Ma}}+50$ males Armatus or Maculatus) or a ratio of $2 \cdot 1: 1$, a slight excess of Black.

If the viability of homozygous $\mathrm{Y}_{\mathrm{Ar}} \mathrm{Y}_{\mathrm{Ar}}$ or $\mathrm{Y}_{\mathrm{Ma}} \mathrm{Y}_{\mathrm{Ma}}$ males were equal to that of the heterozygotes $Y_{A r} Y_{M a}$, the numbers of these two classes should have been equal. Actually, assuming the 50 Armatus or Maculatus individuals above to be YY homozygotes, the ratio becomes $50: 389$, or 1 homozygous YY male : $7 \cdot 8$ heterozygous YY. This clearly indicates a decided inferiority of homozygous to heterozygous YY males in survival. The case, however, is actually much more striking, as the following considerations indicate.

If, in the final crosses listed above, one or more Black $P_{1}$ females of assumed constitution $\mathrm{X}_{\mathrm{Bl}} \mathrm{Y}_{\mathrm{Ar}}$ or $\mathrm{X}_{\mathrm{Bl}} \mathrm{Y}_{\mathrm{Ma}}$ had in fact suffered elimination of the marked $\mathrm{Y}$ chromosome, that event could not immediately be detected, and such an individual might behave genetically as though of constitution $\mathrm{X}_{\mathrm{Bl}} \mathrm{X}_{0}$. When crossed to YY Armatus-Maculatus males, XY males of both Armatus and Maculatus would be expected among the progeny, phenotypically indistinguishable from the corresponding homozygous YY males. Such XY males should be readily distinguishable from YY homozygotes when crossed to $\mathrm{X}_{0} \mathrm{X}_{0}$ females: the former yielding normal bisexual broods in approximately $1: 1$ ratios, the latter predominantly or entirely male progeny.

Accordingly, 15 males of Armatus and 15 males of Maculatus drawn from the questionable group reported in $2(a)$ above (representing a sample of 30 males out of the total of 50 ) were crossed with $\mathrm{X}_{0} \mathrm{X}_{0}$ wild type females, and the sexes in samples of their $F_{1}$ progeny recorded at maturity. Results are shown in table 2.

Thus, of the sample of Armatus and Maculatus males tested, 28 of the 30 proved almost certainly to be of XY constitution. A single Armatus proved probably, and a single Maculatus male certainly, of homozygous YY constitution. These two were both as viable and fertile as XY or heterozygous 
YY males. Assuming that the proportion of such homozygous YY males in the untested sample of 8 males of Armatus and 12 males of Maculatus was the same as in the tested samples of 15 each, the total number of such males expected would be about $3 \cdot 3$.

TABLE 2

\begin{tabular}{|c|c|c|c|}
\hline $\begin{array}{l}\text { Parent male } \\
\text { No. }\end{array}$ & $\underset{\text { counted }}{\text { Number } F_{1} \text { males }}$ & $\begin{array}{c}\text { Number } F_{1} \text { females } \\
\text { counted }\end{array}$ & $\begin{array}{c}\text { Presumed } \\
\text { constitution } \\
\text { of parent male }\end{array}$ \\
\hline \multicolumn{4}{|l|}{ Armatus } \\
\hline 1 & 26 & 26 & $X Y$ \\
\hline 2 & 21 & 33 & $\mathrm{XY}$ \\
\hline 3 & 35 & 50 & $X Y$ \\
\hline 4 & 29 & 37 & $X Y$ \\
\hline 5 & 47 & 55 & $\mathrm{XY}$ \\
\hline 6 & 28 & 64 & $X Y$ \\
\hline 7 & 23 & 34 & $X Y$ \\
\hline 8 & 27 & 20 & $\mathrm{XY}$ \\
\hline 9 & 34 & 24 & $\mathrm{XY}$ \\
\hline 11 & 53 & 68 & $\mathrm{XY}$ \\
\hline 12 & 27 & 24 & $\mathrm{XY}$ \\
\hline 20 & 31 & 32 & $\mathrm{XY}$ \\
\hline 21 & 33 & 26 & $X Y$ \\
\hline 30 & 16 & 14 & $X Y$ \\
\hline Totals & 430 & 507 & \\
\hline$* 10$ & 17 & 0 & YY? \\
\hline \multicolumn{4}{|l|}{ Maculatus } \\
\hline 1 & 38 & 24 & $X Y$ \\
\hline 2 & 22 & 48 & $\mathrm{XY}$ \\
\hline 3 & 23 & 34 & $\mathrm{XY}$ \\
\hline 4 & 37 & 28 & $\mathrm{XY}$ \\
\hline 5 & 39 & 24 & $X Y$ \\
\hline 6 & 23 & 33 & $X Y$ \\
\hline 7 & 36 & 24 & $X Y$ \\
\hline 8 & 4 & 14 & $\mathrm{XY}$ \\
\hline 9 & 23 & 32 & $\mathrm{XY}$ \\
\hline 10 & 2 & 4 & $\mathrm{XY}$ \\
\hline 12 & 31 & 54 & $\mathrm{XY}$ \\
\hline 20 & 12 & 9 & $\mathrm{XY}$ \\
\hline 24 & 32 & 28 & $\mathrm{XY}$ \\
\hline 25 & 28 & 46 & $X Y$ \\
\hline Totals & 350 & 402 & \\
\hline$* 11$ & 267 & 0 & $Y Y$ \\
\hline
\end{tabular}

The ratio given in 2 (a) above of 50 males (hypothetically) homozygous YY: 389 known heterozygous YY males, or $1: 7.8$ then becomes in fact: $3.3: 389$, or a ratio in favour of heterozygotes of $117 \cdot 9: 1$. It thus seems clear beyond doubt that homozygous $\mathrm{YY}$ males of constitution $\mathrm{Y}_{\mathrm{Ar}} \mathrm{Y}_{\mathrm{Ar}}$ and $\mathrm{Y}_{\mathrm{Ma}} \mathrm{Y}_{\mathrm{Ma}}$ are far less viable than heterozygous males of constitution $\mathrm{Y}_{\mathrm{Ar}} \mathrm{Y}_{\mathrm{Ma}}$, and indeed reach maturity on average in less than 1 per cent. of cases.

Further analysis has been made of the situation in the $\mathrm{Y}_{\mathrm{Ma}} \mathrm{Y}_{\mathrm{Ma}}$ male (No. 11 in table 2 above). It suggests that in this individual the lethal 
locus on one $\mathrm{Y}$ chromosome may have been eliminated, through cross-over or other chromosome accident, in an earlier cross and that the male therefore was, in fact, heterozygous for the lethal. This case will be examined further under Discussion.

In the work of Winge (1934) and of Winge and Ditlevsen (1938), the heterozygote $\mathrm{Y}_{\mathrm{Ma}} \mathrm{Y}_{\mathrm{Pa}}$ males were viable and fertile, the homozygous $\mathrm{Y}_{\mathrm{Ma}} \mathrm{Y}_{\mathrm{Ma}}$ males deficient or wholly non-viable. No determination could be made of the viability of $\mathrm{Y}_{\mathrm{Pa}} \mathrm{Y}_{\mathrm{Pa}}$ males. For reasons to be detailed, it seemed important to determine this.

The crosses involved in preparing the foundation stock of $\mathrm{Y}_{\mathrm{Ar}} \mathrm{Y}_{\mathrm{Pa}}$ males were fully successful, and without aberration, and need not be detailed (see plate IV, a-c). Adequate numbers of such males were readily obtained. That they were fully fertile, as well as fully viable, was demonstrated in back-crosses conducted with females of $\mathrm{X}_{0} \mathrm{X}_{0}$ constitution shown in table 3 (see plate V).

TABLE 3

$\begin{array}{ccccc}\begin{array}{c}\text { Cross from which } \\ \text { male } \mathrm{Y}_{\mathrm{Ar}} \mathrm{Y}_{\mathrm{PB}_{\mathrm{B}} \text { derived }}\end{array} & \mathrm{F}_{1} \text { males } & \mathrm{F}_{1} \text { males } & \mathrm{F}_{1} \text { males } & \\ \mathrm{Pa} & \mathrm{Ar} & \mathrm{Pa}-\mathrm{Ar} & \text { Females } \\ \begin{array}{c}\text { Female } \mathrm{X}_{0} \mathrm{Y}_{\mathrm{Ar}} \\ \times \text { male } \mathrm{X}_{0} \mathrm{PPa}_{\mathbf{P a}}\end{array} & 113 & 116 & 0 & 20\end{array}$

As no $\mathrm{F}_{\mathbf{1}}$ males from this cross exhibited both $\mathrm{Ar}$ and $\mathrm{Pa}$ patterns (unlike the situation already detailed for back-crosses of $\mathrm{Y}_{\mathrm{Ar}} \mathrm{Y}_{\mathrm{Ma}}$ males), no further back-crosses were required.

\section{Viability of the homozygote}

The results of the second series of crosses, designed to determine the viability of $\mathrm{Y}_{\mathrm{Pa}} \mathrm{Y}_{\mathrm{Pa}}$ males, are shown below (see plate $\mathrm{VI}$ ).

Female $\mathrm{X}_{\mathrm{Bl}} \mathrm{Y}_{\mathrm{Ar}}$ or $\mathrm{X}_{\mathrm{Bl}} \mathrm{Y}_{\mathrm{Pa}} \times$ male $\mathrm{Y}_{\mathrm{Ar}} \mathrm{Y}_{\mathrm{Pa}}$, yielding 118 males $\left(\mathrm{X}_{\mathrm{Bl}} \mathrm{Y}_{\mathrm{Ar}}\right.$ or $\left.\mathrm{X}_{\mathrm{B} 1} \mathrm{Y}_{\mathrm{Pa}}\right)+84$ males $\mathrm{Y}_{\mathrm{Ar}} \mathrm{Y}_{\mathrm{Pa}}+0$ males $\mathrm{Y}_{\mathrm{Ar}} \mathrm{Y}_{\mathrm{Ar}}+0$ males $\mathrm{Y}_{\mathrm{Pa}} \mathrm{Y}_{\mathrm{Pa}}+36$ Black females.

If the homozygous YY class of males is inviable, then the ratio of total Black individuals (of Black X-chromosome-containing individuals, male or female) to $P a-A r$ males should be $2: 1$. The actual ratio is $(113+36=149$ Black : $81 \mathrm{Y}_{\mathrm{Pa}} \mathrm{Y}_{\mathrm{Ar}}$, or $1 \cdot 8: 1$.

No homozygous $\mathrm{Y}_{\mathrm{Pa}} \mathrm{Y}_{\mathrm{Pa}}$ males appear to have survived to maturity in any of the crosses. They appear, without exception, to have been inviable.

\section{Discussion}

Thus it seems clear that there is a recessive lethal, linked to each of the Y-linked pattern supergenes Maculatus, Armatus and Pauper, effectively suppressing homozygosity in YY males. YY males heterozygous for any two such lethals, however, appear to be essentially as viable and fertile as normal XY males.

This finding raises the intriguing possibility that in wild populations of Lebistes many recessive lethals of this kind may exist, linked to different pattern supergenes, and constituting no barrier to the appearance of heterozygous YY males carrying them in combination. Such lethals, however, 
would be expected to render $\mathrm{XY}$ males homozygous for them as inviable as the corresponding YY males, and so should constitute a powerful barrier to crossing-over between $\mathrm{Y}$ and $\mathrm{X}$ at such loci.

That it is indeed associated lethals, and not the colour pattern supergenes themselves, that are responsible is strongly suggested by the fact that colourpattern supergenes which behave as though linked to the $\mathrm{X}$ chromosome or to autosomes (and which frequently exhibit measurable cross-over values) do not reduce either viability or fertility when homozygous. Winge (1927) reported males homozygous for the autosomally linked pattern locus Zebrinus and for the pattern Elongatus in $\mathrm{X}$ and $\mathrm{Y}$, and these were viable and fertile.

We have considered it worth while to further confirm this situation in females homozygous for two further X-linked supergenes: Coccineus-Vitellinus and Melano-Dorsal. Fertile females were selected at random from pure mass cultures of these stocks, and subcultures established from each individual. Males appearing in these subcultures were scored over a period of time. The results are shown in table 4 . Thus, in these four randomly chosen females homozygosity for the character in question was evidently no barrier to either viability or fertility.

\section{TABLE 4}

\begin{tabular}{|c|c|c|c|}
\hline \multicolumn{2}{|c|}{ No. female } & $\begin{array}{c}\text { No. } F_{1} \text { males } \\
\text { showing character }\end{array}$ & $\begin{array}{c}\text { No. } F_{1} \text { males } \\
\text { without character }\end{array}$ \\
\hline $\mathrm{PaCoVi}$ & 1 & 128 & 14 showing cross-over \\
\hline & 2 & 142 & 0 \\
\hline$P a-M d$ & $\begin{array}{l}1 \\
2\end{array}$ & $\begin{array}{r}70 \\
128\end{array}$ & $\begin{array}{l}0 \\
0\end{array}$ \\
\hline
\end{tabular}

Such considerations lend special interest to the situation in the single highly viable and fertile male of the constitution $\mathrm{Y}_{\mathrm{Ma}} \mathrm{Y}_{\mathrm{Ma}}$ reported earlier.

In an interesting series of investigations of the sex-linked recessive character Red-Gold in the Japanese Medaka (Oryzias latipes) Yamamoto (1953, $1955,1958,1959 a, b, 1964 a, b, 1965,1967)$ was able to confirm and extend, on a much larger scale and with better controlled material, earlier work of Aida $(1921,1930,1936)$ on the same mutation. Red-Gold is a sex-linked character, recessive to wild type, which suppresses the formation of melanin in the body pigmentation. It is allelic with and dominant to the factor White. It shows relatively high cross-over values between $\mathrm{X}$ and $\mathrm{Y}$.

By using mammalian hormones in procedures similar to our own to induce sex-reversal artificially, Yamamoto was able to produce at will, and in quantity, both $\mathrm{XY}$ and $\mathrm{YY}$ females and $\mathrm{YY}$ males, and to demonstrate their viability and fertility. He also demonstrated that, while normal RedGold males $\left(\mathrm{XY}_{\mathbf{R}}\right)$, white males $\left(\mathrm{Y}_{\mathrm{r}} \mathrm{Y}_{\mathbf{r}}\right)$ and estrone-induced white females $\left(\mathrm{Y}_{\mathbf{r}} \mathrm{Y}_{\mathbf{r}}\right)$ are fully viable, homozygous $\operatorname{Red}$-Gold males $\left(\mathrm{Y}_{\mathbf{R}} \mathrm{Y}_{\mathbf{R}}\right)$ are, with very few exceptions, lethal. The analogy with the lethal nature of homozygotic YY males in Lebistes here studied seems suggestively close, except that in Oryzias the lethality is not associated with zero cross-over values from $\mathrm{Y}$ to $\mathrm{X}$.

Yamamoto interpreted the inviability of homozygous Red-Gold YY males as due to a closely linked lethal condition which, for a variety of reasons, 
he regarded as an inert section of the chromosome. Occasional viable YY Red-Gold males he interpreted as the result of cross-over in one Y chromosome, eliminating the inert section.

It seemed pertinent, therefore, to inquire whether the viable and fertile $\mathrm{Y}_{\mathrm{Ma}} \mathrm{Y}_{\mathrm{Ma}}$ might not, in fact, have arisen from a zygote in which a cross-over event between the colour factor and the associated lethal had occurred in one $\mathrm{Y}$ chromosome. Such a hypothetical individual may be represented by the formula $\mathrm{Y}_{\mathrm{Ma}} \mathrm{Y}_{\mathrm{Ma}}$, where $\mathrm{Ma}^{\prime}$ lies in the $\mathrm{Y}$ chromosome from which the lethal was eliminated.

Crosses were made between females of constitution $\mathrm{X}_{\mathrm{Bl}} \mathrm{X}_{\mathrm{Bl}}$ and the exceptional male $\mathrm{Y}_{\mathrm{Ma}} \mathrm{Y}_{\mathrm{Ma}}$, and these were treated with estrone as larvae, in the fashion already described, yielding adult functional females, presumably of two classes, $\mathrm{X}_{\mathrm{Bl}} \mathrm{Y}_{\mathrm{Ma}}$ and $\mathrm{X}_{\mathrm{Bl}} \mathrm{Y}_{\mathrm{Ma}}$. When these were back-crossed to the original male, the ratios of Black (XY) to non-Black (YY) progeny should be $1: 1$, assuming full viability of the $\mathrm{Y}_{\mathrm{Ma}} \mathrm{Y}_{\mathrm{Ma}}$ or $\mathrm{Y}_{\mathrm{Ma}}, \mathrm{Y}_{\mathrm{Ma}}$, class. If either or both of these classes are inviable, but $\mathrm{Y}_{\mathrm{Ma}} \mathrm{Y}_{\mathrm{Ma}}$ males are viable, the ratio of Black to non-Black should be $2: 1$.

Among 266 young bred from such a back-cross to one female, there were 128 Black males $\left(\mathrm{X}_{\mathrm{Bl}} \mathrm{Y}_{\mathrm{Ma}}\right.$ or $\mathrm{X}_{\mathrm{Bl}} \mathrm{Y}_{\mathrm{Ma}^{\prime}}$ ), 68 Black females (probably $\mathrm{XY}$, and of the same constitution as the Black males), and 70 non-Black, typically $M a$ males. The ratio of total Blacks to uncoloured males was thus $196: 70$, or 2.8 Black : 1 uncoloured. This suggests that the homozygous YY males were lethal in this cross, but the hypothetically heterozygous $\mathrm{Y}_{\mathrm{Ma}} \mathrm{Y}_{\mathbf{M a}}$, males survived. The lethal factor normally linked to Maculatus thus must have been modified or eliminated by cross-over in the exceptional parent $\mathrm{Y}_{\mathrm{Ma}} \mathrm{Y}_{\mathrm{Ma}}$ male.

As a matter of interest in connection with the mode of sex determination in Lebistes, 3 of the Maculatus males from this progeny (which might be presumed of $\mathrm{XY}$ constitution) were again back-crossed to females of $\mathrm{X}_{0} \mathrm{X}_{0}$ constitution. The first yielded $32 \mathrm{~F}_{1}$ male Maculatus and only 5 females ( 3 of which proved to be Maculatus); the second only $4 \mathrm{~F}_{1}$ Maculatus males; the third $7 \mathrm{~F}_{1}$ Maculatus males and 7 females, 6 of which, like the 3 of the second cross, proved typical Maculatus when treated with methyl testosterone. Thus it would appear that all 3 of these males were indeed homozygous for the Maculatus pattern, though distribution of sex-determining genes-and their balance-was variable.

\section{SUMmary}

1. Using methods of artificial sex reversal with mammalian hormones, and employing as an X-chromosome marker a dominant X-linked mutation for body colouration relatively newly arisen in aquarium stock of Lebistes (frequently called " Half-Black") which is not sex-limited in expression and becomes phenotypically evident in young only a few days old, it has been possible to prepare at will considerable numbers of $\mathrm{XY}$ females for use in investigating the viability and fertility of $Y Y$ males and of females of constitution both $\mathrm{XY}$ and $\mathrm{YY}$.

2. Using such material, it has been demonstrated that $Y Y$ males homozygous at the "absolutely" Y-linked locus Maculatus are non-viable, suggesting the presence of a recessive lethal factor closely linked to the Maculatus locus. This confirms earlier more limited findings of Winge. 
3. Winge demonstrated that males heterozygous for Maculatus and for a second "absolutely" Y-linked colour pattern supergene, Pauper, were, on the other hand, fully viable and fertile, suggesting either that there is no corresponding recessive lethal closely linked to Pauper, or that, if such a lethal is present, it is non-allelic to that linked to the Maculatus locus. This latter conclusion would be most interesting, but these alternative possibilities cannot be distinguished from Winge's data.

4. YY males heterozygous for Maculatus and for Armatus, a third " absolutely" Y-linked pattern originally described by Winge, and also heterozygous for Pauper and Armatus have been prepared. Both proved fully viable and fertile. Males homozygous for Pauper and Armatus, however, proved lethal, like those homozygous for Maculatus. This seems to offer good evidence that a series of non-allelic, recessive lethals may be linked to Maculatus, Armatus and Pauper.

5. In back-crosses to females of constitution $\mathrm{X}_{0} \mathrm{X}_{0}$ (respecting sex-linked colour patterns) males heterozygous for both Maculatus and Armatus and Pauper and Armatus produced, as expected, approximately equal numbers of male progeny of constitution $\mathrm{X}_{0} \mathrm{Y}_{\mathrm{Ma}}$ and $\mathrm{X}_{0} \mathrm{Y}_{\mathrm{Ar}}$ and $\mathrm{Y}_{0} \mathrm{Y}_{\mathrm{Pa}}$ and $\mathrm{X}_{0} \mathrm{Y}_{\mathrm{Ar}}$ respectively, indicating that cross-over between $\mathrm{Y}$ chromosomes had not occurred.

6. A single example of a fully viable YY male homozygous for Maculatus is described. In this individual the lethal may have been modified in, or eliminated from, one of the $\mathrm{Y}$ chromosomes, so that it was, in effect, heterozygous for the lethal. In crosses with $\mathrm{X}_{0} \mathrm{X}_{0}$ females it proved fully fertile, giving rise to numerous male progeny only, all of the Maculatus pattern. This male may well have illustrated a situation generally analogous to that described by Yamamoto in Oryzias, and interpreted by him as a consequence of cross-over between the colour locus and an inert chromosome region adjacent to it.

7. Tests were made of the viability and fertility of $\mathrm{XY}$ males and $\mathrm{XX}$ females homozygous for certain colour pattern supergenes which show measurable cross-over values between $\mathrm{Y}$ and $\mathrm{X}$. Both the supergene Coccineus-Vitellinus and Melano-Dorsal, segregated from wild populations in Trinidad, were associated with full viability and fertility when homozygous in both males and females, suggesting the absence here of recessive lethals.

8. It seems evident that heterozygosity in males with respect to the three " absolutely" Y-linked colour factors so far investigated can be importantly stabilised in populations containing them through the action of a series of closely linked recessive genes which are lethal when homozygous, but which appear to be non-allelic among the three pattern supergenes. The possibility that this may be a rather general mechanism stabilising male heterozygosity in wild populations of Lebistes is being investigated, using a series of pattern supergenes from wild Trinidad populations that are similarly " absolutely" Y-linked.

9. The question of whether the non-allelism of the lethal factors linked to Maculatus, Armatus, and Pauper can be referred to single loci or reflect polygenic phenomena within the respective $Y$ chromosomes is interesting and significant. For the present, it will be conservative to refer to the Maculatus, Pauper, and Armatus-bearing Y chromosomes as a whole as nonallelic. What may be especially interesting in the present context is the fact that such non-allelic chromosomes can (and regularly do) coexist, 
often in quite balanced and stable proportions, within freely interbreeding local natural populations of Lebistes.

Acknowledgments.-We wish to express our great appreciation to Professor Th. Dobzhansky, of the Rockefeller University, for his kindness in reading and commenting on this paper.

\section{REFERENCES}

AIDA, T. 1921. On the inheritance of color in a fresh-water fish Aplocheilus litapes Temminck and Schlegel, with special reference to the sex-linked inheritance. Genetics, 6, 554-573.

AIDA, T. 1930. Further genetical studies of Aplocheilus latipes. Genetics, 15, 1-16.

AIDA, T. 1936. Sex reversal in Aplocheilus latipes and a new explanation of sex differentiation. Genetics, 21, 136-156.

CLARKE. C. A., AND SHEPPARD, P. M. 1959. The genetics of some mimetic forms of Papilio dardanus Brown and Papilio glaucus Linn. 7. Genetics, 56, 236-260.

CLARKE, C. A., AND SHEPPARD, P. M. 1962. The genetics of the mimetic butterfly Papilio glaucus. Ecology, 43, 159-161.

CURNOW, R. N., CRITCHLEY, MARY J., AND DYER, K. F. 1969. Estimating the degree of allelism of chromosomes carrying lethal recessives. Genetics, 61, 219-226.

DARLington, c. D., AND MATHER, x. 1949. The Elements of Genetics. Macmillan Company, New York.

DOBZHANSKY, T., AND WRIGHT, s. 1941. Genetics of natural populations. V. Relations between mutation rates and accumulation of lethals in populations of Drosophila pseudoobscura. Genetics, 26, 23-51.

Dzwillo, M. 1959. Genetic examinations of the domesticated strains of Lebistes reticulatus. Hamburg Zool. Mus. Inst.

FORD, E. B. 1965. Ecological Genetics. Second edition. Methuen and Co., Ltd., London.

GORDON, M. 1927. The genetics of a viviparous top minnow Platypaecilus; the inheritance of two kinds of melanophores. Genetics, 12, 253-283.

GORDON, M. 1947. Genetics of Platypoecilus maculatus. IV. The sex determining mechanisms in two wild populations of the Mexican platyfish. Genetics, 32, 8-17.

GORDON, M. 1950. Fishes as laboratory animals. The Care and Breeding of Laboratory Animals (ed. E. Farris). John Wiley \& Co., New York, 345-449.

GORDON, M. 1951. The variable expressivity of a pigment cell gene from zero effect to melanotic tumor induction. Cancer Res., 11, 676-686.

GROBSTEIN, c. 1948. Optimal gonopodial morphogenesis in Platypoecilus maculatus with constant dosage of methyl testosterone. 7. Exp. Zool., 109, 215-233.

HASKINS, c. P., AND HASKINS, E. F. 1950. Factors governing sexual selection as an isolating mechanism in the Poeciliid fish Lebistes reticulatus. Proc. Nat. Acad. Sci., 36, 464-476.

HASKINS, C. P., AND HASKINS, E. F. 1951. The inheritance of certain color patterns in wild populations of Lebistes reticulatus in Trinidad. Evolution, 5, 216-225.

HASKINS. C. P., AND HASKINS, E. F. 1954. Note on a "permanent" alteration of genetic constitution in a natural population. Proc. Nat. Acad. Sci., 40, 627.635.

haskins, C. P., haskins, E. F., MCLAUGhlin, J. J. A., AND heWrT, R. E. 1961. Polymorphism and population structure in Lebistes reticulatus. Vertebrate Speciation (ed. W. Frank Blair). Univ. Texas Press, Austin, 320-395.

MANN, J. D. et al. 1962. A sex-linked blood group. Lancet, 1, 8-10.

scHmid, J. 1920. Racial investigations. IV. The genetic behavior of a secondary sexual character. C. R. Lab. Carlsberg Ser. Physiol., 14, 8.

WINGE, $\mathscr{\varnothing}, 1922 a$. A peculiar mode of inheritance and its cytological explanation. F. Gen., $12,137$.

WINGE, Ø. 1922b. One-sided masculine and sex-linked inheritance in Lebistes reticulatus. 7. Gen., 12, 145-162.

WINGE, ø. 1923. Crossing-over between the X-and Y-chromosomes in Lebistes. F. Gen. $13,201$.

WINGE, ø. 1927. The location of eighteen genes in Lebistes reticulatus. 7. Gen., 18, 1-43.

WINGE, ø. 1930. On the occurrence of XX males in Lebistes, with some remarks on Aida's so-called " non-disjunctional" males in Aplocheilus. 7. Gen., 23, 69-76.

WINGE, Ø. 1934. The experimental alteration of sex chromosomes into autosomes, and vice versa, as illustrated by Lebistes. C. R. Lab. Carlsberg Ser. Physiol., 21, 1-49.

WINGE, Ø., AND DITLEVSEN, E. 1938. A lethal gene in the $\mathrm{Y}$ chromosome of Lebistes. C. R. Lab. Carlsberg Ser. Physiol., 22, 203-211. 


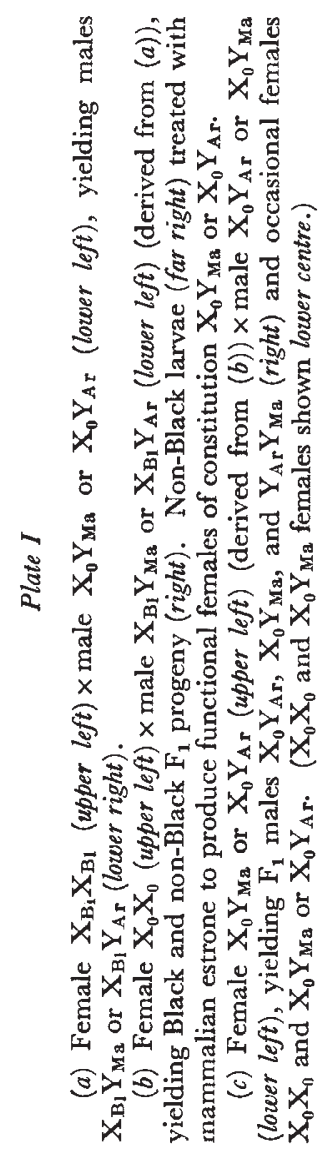


1111

1111

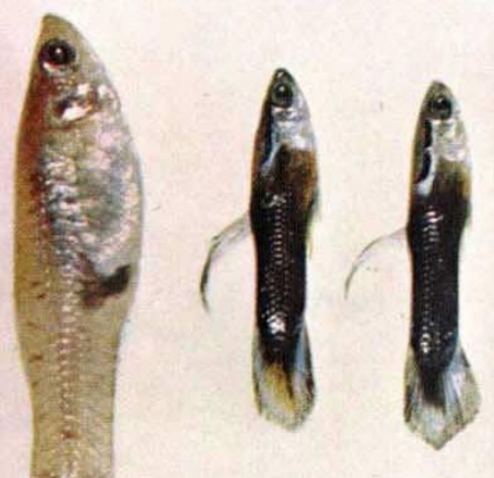

D
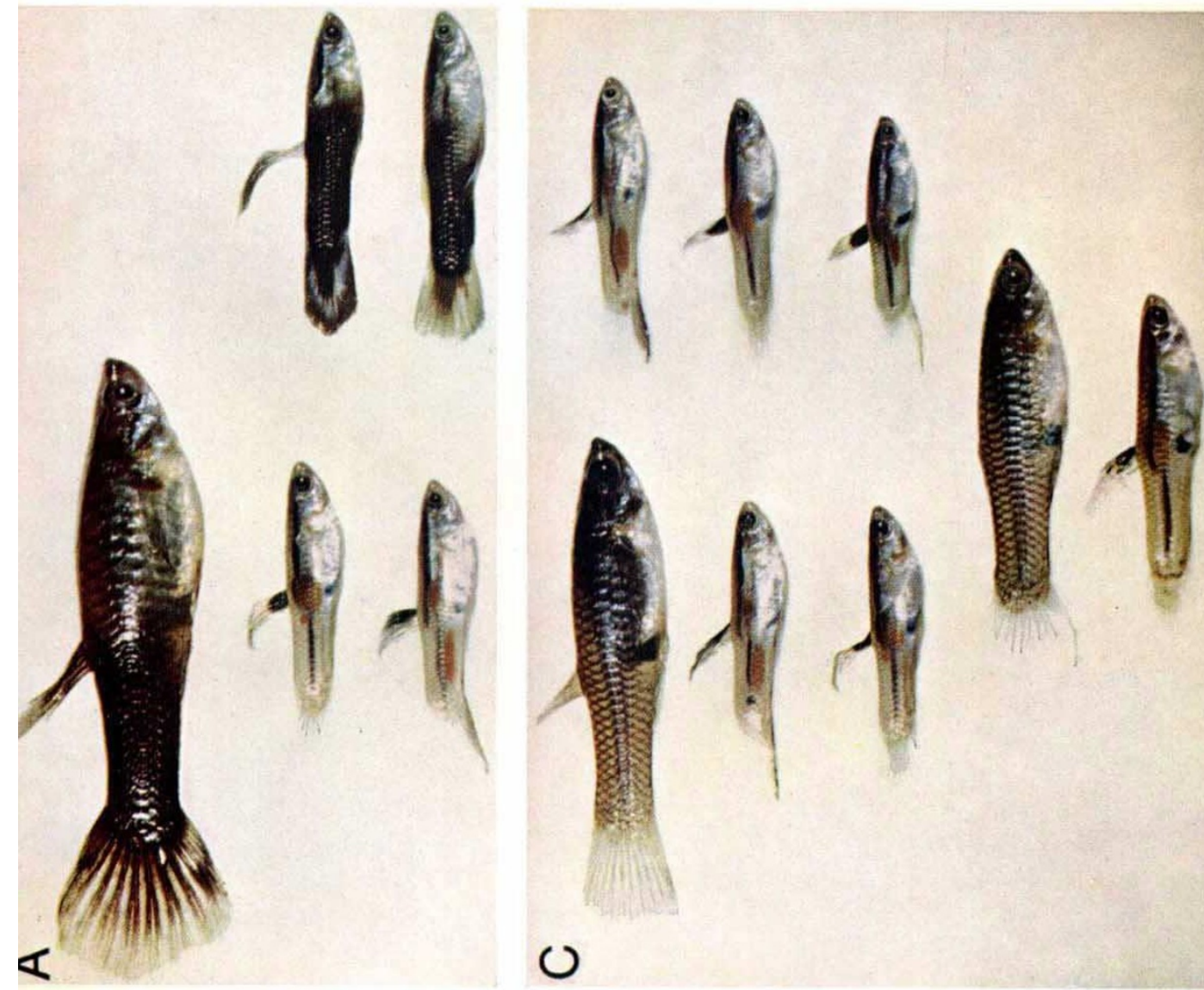

0 
(a) Males $\mathrm{X}_{0} \mathrm{Y}_{\mathrm{Ma}}$ (left); males $\mathrm{Y}_{\mathrm{Ar}} \mathrm{Y}_{\mathrm{Ma}}$ (right).

(b) Males $\mathrm{X}_{0} \mathrm{Y}_{\mathrm{Ar}}$ (left); males $\mathrm{Y}_{\mathrm{Ar}} \mathrm{Y}_{\mathrm{Ma}}($ right $)$. 


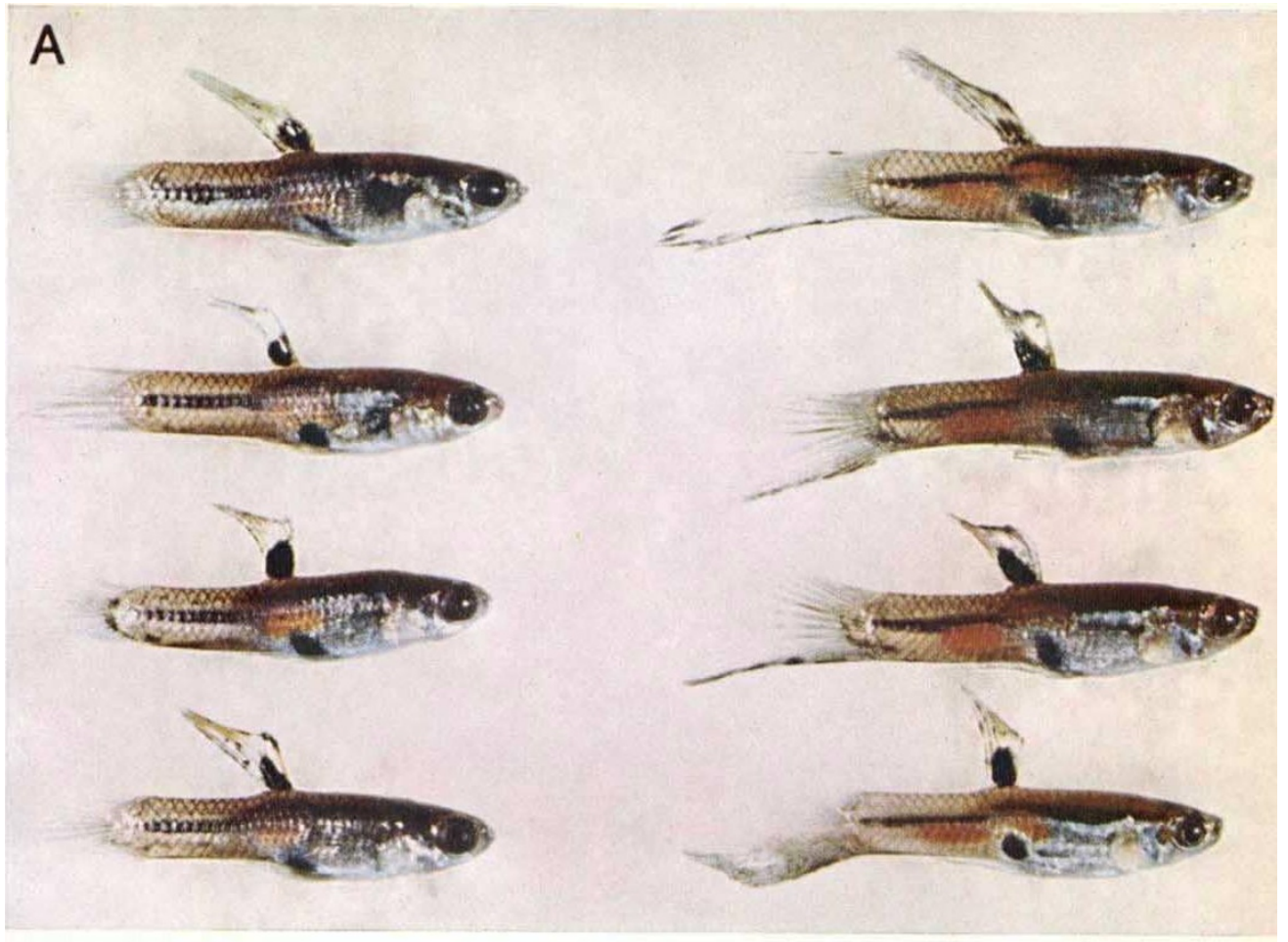

B

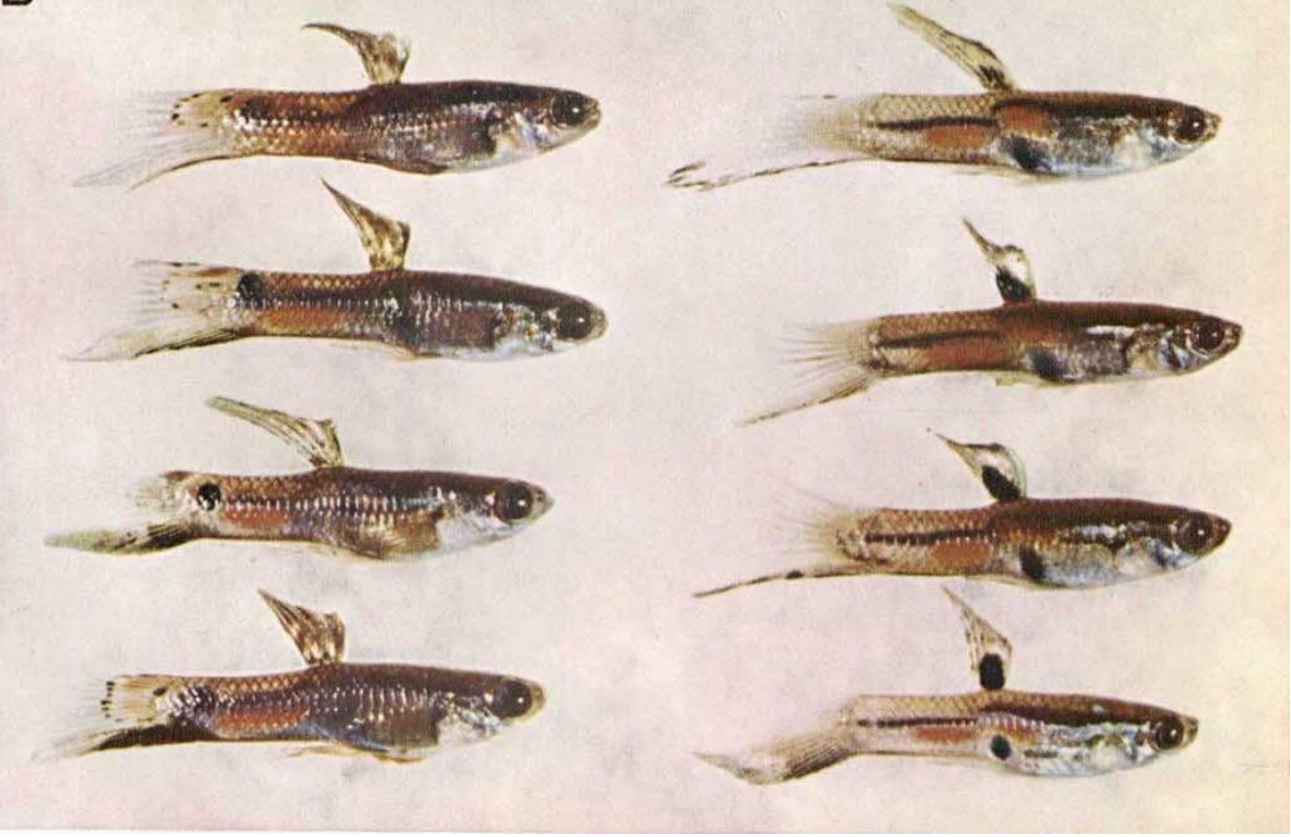




\section{Plate III}

(a) Female $\mathrm{X}_{\mathrm{B}_{1}} \mathrm{X}_{\mathrm{Bi}}$ (upper left) $\times$ male $\mathrm{X}_{0} \mathrm{Y}_{\mathrm{Ar}}$ or $\mathrm{X}_{0} \mathrm{Y}_{\mathrm{Ma}}$ (lower left) yielding $\mathrm{F}_{1}$ progeny $\mathrm{X}_{\mathrm{B} 1} \mathrm{Y}_{\mathrm{Ar}}$ or $\mathrm{X}_{\mathrm{B}_{1}} \mathrm{Y}_{\mathrm{Ma}}$. These treated as larvae with mammalian estrone to yield functional females.

(b) Female $\mathrm{X}_{\mathrm{B}_{1}} \mathrm{Y}_{\mathrm{Ma}}$ or $\mathrm{X}_{\mathrm{B}_{1}} \mathrm{Y}_{\mathrm{Ar}}$ (upper left) (derived from (a)) $\times$ male $\mathrm{Y}_{\mathrm{Ma}} \mathrm{Y}_{\mathrm{Ar}}$ (lower left), yielding males $\mathrm{X}_{\mathrm{B}_{1}} \mathrm{Y}_{\mathrm{Ma}}, \mathrm{X}_{\mathrm{B}_{1}} \mathrm{Y}_{\mathrm{Ar}}$, and $\mathrm{Y}_{\mathrm{Ma}} \mathrm{Y}_{\mathrm{Ar}}$ (right).

The homozygous classes $Y_{\mathrm{Ma}} \mathrm{Y}_{\mathrm{Ma}}$ and $\mathrm{Y}_{\mathrm{Ar}} \mathrm{Y}_{\mathrm{Ar}}$ failed to be detected except in two aberrant cases. One, of constitution $\mathrm{Y}_{\mathrm{Ma}} \mathrm{Y}_{\mathrm{Ma}}$, discussed in text, shown at bottom. 


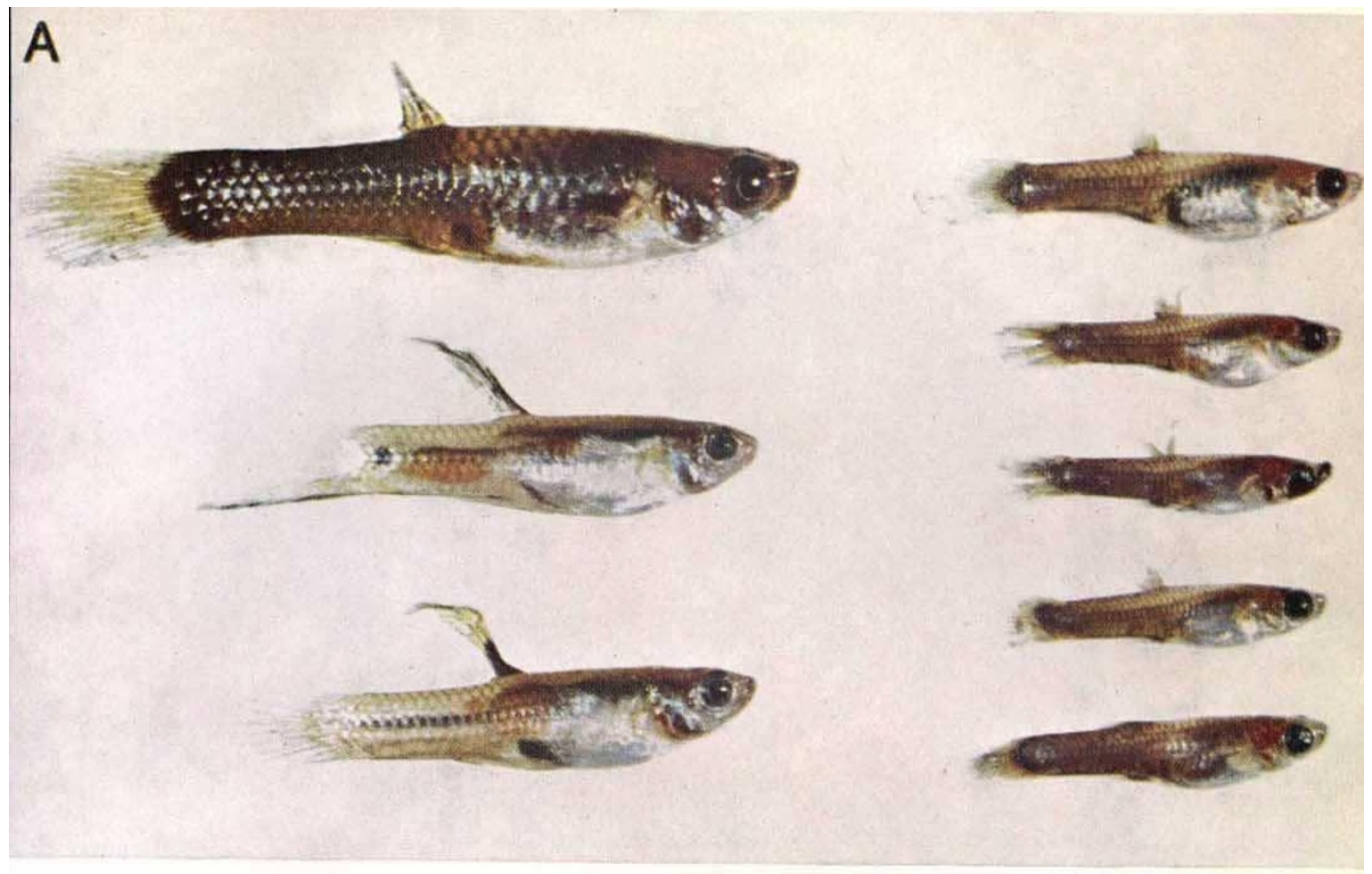

B
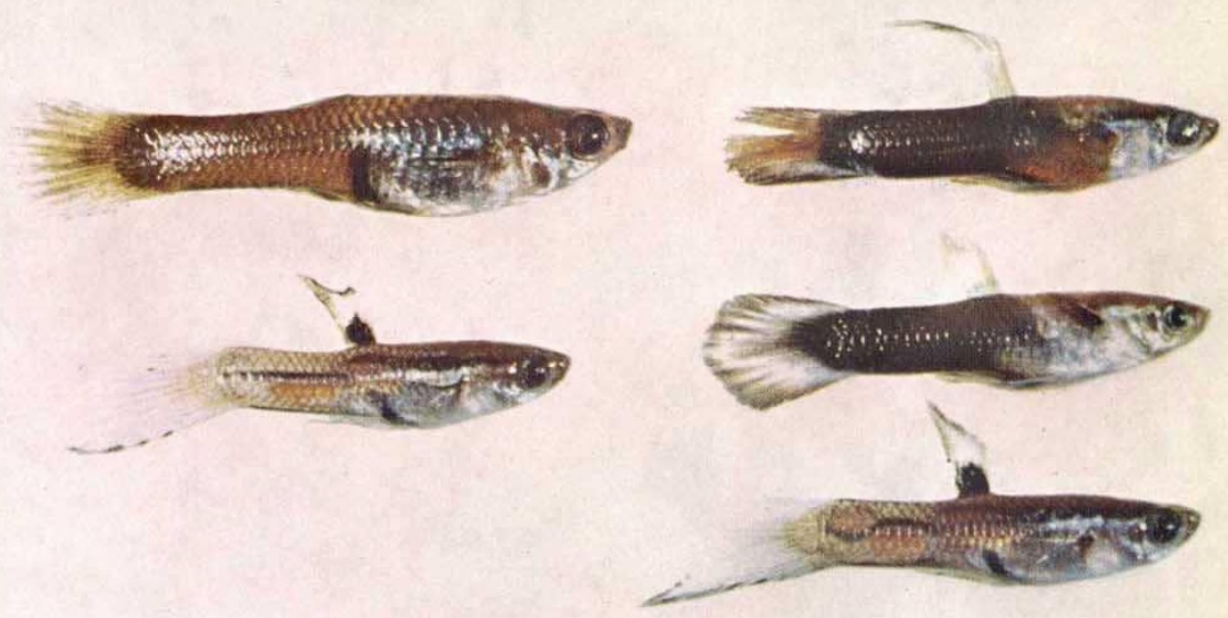


\section{Plates V and VI}

Plate $\mathrm{V}$ (top). Back-cross of male $\mathrm{Y}_{\mathrm{Ar}} \mathrm{Y}_{\mathrm{Pa}}$ to female $\mathrm{X}_{0} \mathrm{X}_{0}$. Male $\mathrm{Y}_{\mathrm{Ar}} \mathrm{Y}_{\mathrm{Pa}}$ (upper left) $\times$ female $\mathrm{X}_{0} \mathrm{X}_{0}$ (upper right), yielding males $\mathrm{X}_{0} \mathrm{Y}_{\mathrm{Ar}}$ (lower left) and $\mathrm{X}_{0} \mathrm{Y}_{\mathrm{Pa}}$ (lower right).

Plate VI (bottom). Crosses to test viability of homozygous $Y_{A r} Y_{A r}$ and $Y_{P R} Y_{P a}$ males. Female $\mathrm{X}_{\mathrm{B}_{1}} \mathrm{Y}_{\mathrm{Ar}}$ or $\mathrm{X}_{\mathrm{B}_{1}} \mathrm{Y}_{\mathrm{Pa}}$ (prepared as already illustrated) (upper left) $\times$ male $\mathrm{Y}_{\mathrm{Ar}} \mathrm{Y}_{\mathrm{Pa}}$ (lower left), yielding males $\mathrm{X}_{\mathrm{B}_{1}} \mathrm{Y}_{\mathrm{Ar}}$ or $\mathrm{X}_{\mathrm{B}_{1}} \mathrm{Y}_{\mathrm{Pa}}$, and $\mathrm{Y}_{\mathrm{Ar}} \mathrm{Y}_{\mathrm{Pa}}$ (right). No homozygous $\mathrm{YY}$ male, $Y_{A r} Y_{A r}$ or $Y_{P a} Y_{P a}$, nor females, ever detected in this cross. 


$$
\begin{aligned}
& \text { HIII } \\
& \text { IIII } \\
& 111 \\
& 11111 \\
& \text { |HIII }
\end{aligned}
$$




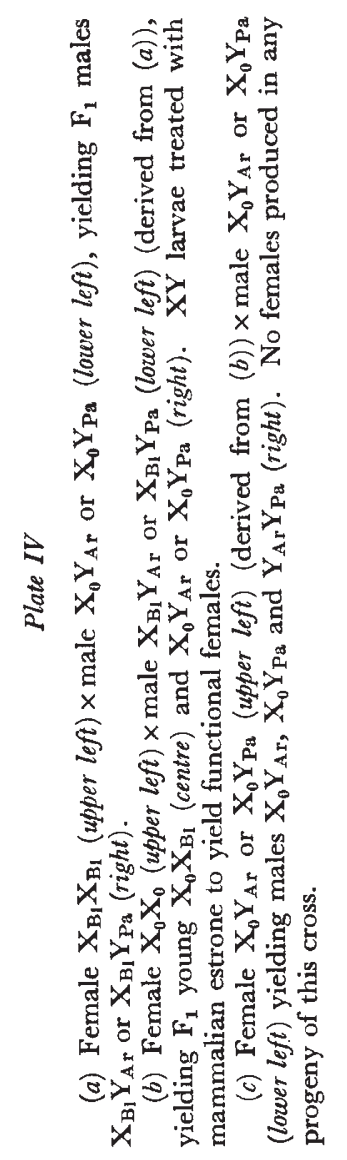



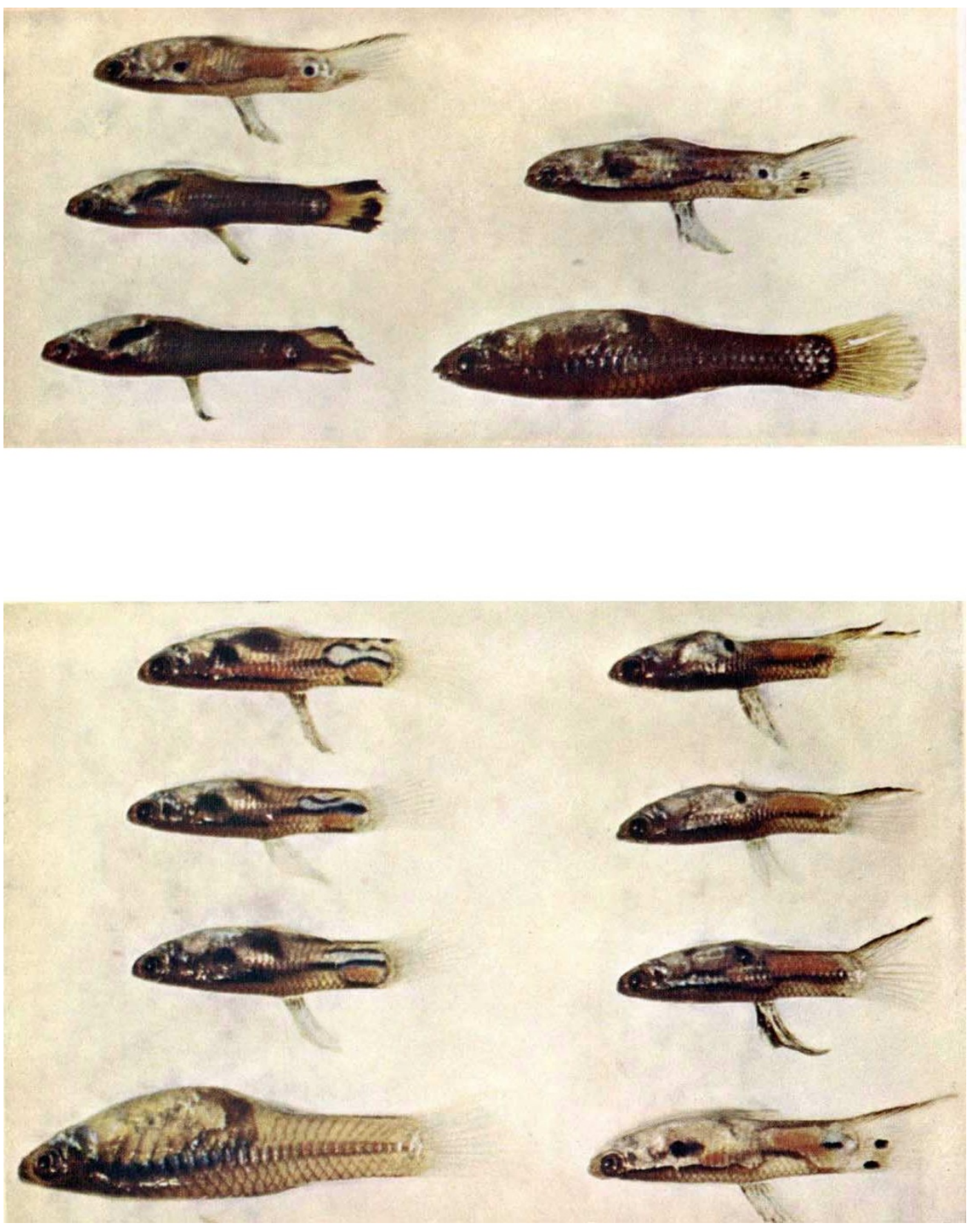
уамамото, т. 1953. Artificially induced sex reversal in genotypic males of the Medaka (Oryzias latipes). F. Exp. Zool., 123, 571-594.

уамлмото, т. 1955. Progeny of artificially induced sex reversals of male genotype (XY) in the Medaka (Oryzias latipes) with special reference to YY males. Genetics, 40, 406-419. уамамото, т. 1958. Artificial induction of functional sex reversal in genotypic females of the Medaka (Oryzias latipes). F. Exp. Zool., 137, 227-264.

уамамото, т. 1959a. The effects of estrone dosage level upon the percentage of sex reversals in genetic male (XY) of the Medaka (Oryzias latipes). F. Exp. Zool., 141, 133-154.

уамамото, т. 1959b. A further study of induction of functional sex reversal in genotypic males of the Medaka (Oryzias latipes) and progenies of sex reversals. Genetics, 44, 739-757. уамамото, т. 1964a. The problem of viability of YY zygotes in the Medaka (Oryzias latipes). Genetics, 50, 45-58.

уамамото, т. 1964b. Linkage map of sex chromosomes in the Medaka (Oryzias latipes). Genetics, 50, 59-64.

yамамото, т. 1965. Estriol-induced XY females in the Medaka Oryzias latipes. Gen. Comp. Endocrinol., 5, 527-533.

Yамамото, T. 1967. Estrone-induced white YY females and mass production of YY males in the Medaka, Oryzias latipes. Genetics, 55, 329-336. 